\title{
BERDAKWAH DITENGAH SITUASI PANDEMI
}

\author{
Hastina \\ Komunikasi dan Penyiaran Islam - Fakultas Ushuluddin Adab dan Dakwah \\ Institut Agama Islam Negeri Parepare \\ hastina@iainpare.ac.id
}

\begin{abstract}
Pandemic today is very influential on our daily lives. Not just doing activities at home, but all our activities are all at home. Not like preaching that we usually know is done face-to-face directly to mad'u mad'u at the same time chatting and interacting directly with the general public. But that's all in the current pandemic situation we are very difficult to do that, other than for government reasons that encourage us to stay at home, but also for other reasons namely because of health protocols that must be obeyed, to break the chain of the spread of the pandemic virus that is epidemic recently. There are so many applications that we can use to expedite preaching virtually for example such as Zoom Cloud Meeting, Webbex, Skypey and many more.
\end{abstract}

Keywords : dakwah and pandemic, covid-19

\begin{abstract}
Abstrak
Pandemic sekarang ini sangat berpengaruh terhadp kehidupan keseharian kita. Bukan hanya sekedar melakukan kegiatan hanya dirumah saja namun segala aktifitas aktifitas kitapun semua serba dirumah saja. Tidak halnya seperti berdakwah yang biasanya kita ketahui dilakukan secara tatap muka secara langsung kepada mad'u mad'u sekaligus bercengkrama dan bersilaturahmi secara langsung kepada khalayak ramai. Namun itu semua di situasi pandemic sekarang ini kita sangatlah susah untuk melakukan itu, selain karena alasan pemerintah yang menganjurkan kita untuk tetap berada dirumah saj, namun juga alas an lainya yaitu karena protocol kesehatan yang harus dipatuhi, untuk memutus rantai penyebaran virus pandemic yang sedang mewabah sekarang ini. Ada banya sekali aplikasi yang dapat kita gunakan untuk memperlancar berdakwah secara virtual contohnya seperti Zoom Cloud Meeting, Webbex, Skypey dan banyk lagi.
\end{abstract}

Kata kunci : dakwah dan pandemic, covid-19

\section{PENDAHULUAN}

\section{Latar belakang}

Dilihat dari maraknya pendakwah yang melakukan dakwah secara virtual, maka dari itu saya ingin mendalami dan meneliti sedikit banyaknya hal hal yang berkesinambungan dengan berdakwah di situasi pandemic ini. Karena banyaknya yang mengklaim bahwa apapun kegiatan yang dilakukakn secara virtual atau online itu biasanya tidak efektif, nah maka dari itu disini saya akan mengkaji sedikit tentang hal tersebut lalu mengkaitkannya dengan situasi kita saat ini, apakah benar hal tersebut tidak efektif? Tetapi dilihat dari banyknya dai'I dai' modern atau da'I da'I anak 
muda yang paham dan melek akan teknologi malah memanfaatkan teknologi atau media social tersebut sebagai ajak untuk mempublish atau membagikan aktifitas mereka sama halnya berdakwah yang mereka lakukan. Jika dilihat dari sudut pandang penyampaiaannya berdakwah secara virtual mungkin saja memiliki lebih banyak penonton atau pendengar atau mad'u karena dilihat dari situas dan kodisi anak milenial sekarang ini yang lebih banyak memiliki waktu bermain dan bercengkrama melalui gadged atu smartphone mereka. Hal ini tentu saja menjadi salah satu peluang bagi banyaknya pendakwah yang kesusahan mencari tempat mana lagi yang harus mereka kunjungi untuk melakukan kegiatan mereka yaitu berdakwah.

\section{Tujuan}

Tujuan dari penelitian ini tidak lain dan tidak bukan ialah mengenali sekaligus menggali informasi ditengah situasi pandemi sekarang ini, apakah efektif jikalau ditengah pandemi sekarang ini kita berdakwah ataukah kita memiliki peluang di tengah pandemi sekarang untuk melakukan kegiatan tersebut. Seperti yang kita ketahui bahwa entah sampai kapan pandemic ini berakhir, namun pemerintah tidak tinggal diam melihat situasi ini. Jadi dengan adanya peelitian ini diharap mampu menjawab tanda Tanya tanda Tanya yang ada di pikiran santri ataupun dai yang ingin berdakwah.

\section{Metode Penelitian}

Jenis metode penelitian yang saya gunakan yaitu metode deskriftif, yaitu metode yang menggunakan beberapa referensi dari artikel ilmiah, artikel jurnal, literature, serta artikel online sebagai bahan pendukung.

\section{PEMBAHASAN}

\section{A. Pengertian Dakwah \& Berdakwah}

Dakwah ( $\underline{\text { Arab: }}$ : da'wah; "ajakan") adalah kegiatan yang bersifat menyeru, mengajak dan memanggil orang untuk beriman dan taat kepada Allah sesuai dengan garis aqidah, syari'at dan akhlak Islam. Kata dakwah merupakan masdar (kata benda) dari kata kerja da'a yad'u yang berarti panggilan, seruan atau ajakan. Berdasarkan pengertian dakwah tersebut dapat disimpulkan bahwa dakwa merupaakan suatau proses atau cara seseorang untuk melakukan ajakan atau seruan kepada sesame ummat atau sesame maklhuk hidup, guna menjaga silaturahmi dan juga menyampaikan ajaran ajaran kebaikan.

Adapun pengertian berdakwah menurut saya yaitu suatu proses seseorang atau Muballiq untuk menyampaikan informasi atau ilmu kepada khalayak umum, baik itu secara langsung maupun secara tidak langsung. Seorang Muballiq baru bisa dikatakan berdakwah apabila melakukan proses tersebut dengan adanya penonton atau pendengar. 


\section{B. Metode Dakwah}

Dari segi bahasa metode berasal dari dua bahasa yaitu "meta" (melalui) dan "hodos" (jalan atau cara). Metode merupakan cara atau jalan yang harus dilakukan untuk mencapai suatu tujuan. Adapun sumber lain menyebutkan bahwa metode berasal dari bahasa jerman yaitu methodica artinya ajaran tentang metode. Ada beberapa metode dakwah dalam Al Qur"ean Surat An Nahl : 125 : hikmah, pelajaran yang baik dan mujadalah. Hal tersebut dapat diambil pemahaman bahwa metode dakwah itu meliputi tiga cakupan. Moh. Ali Aziz dalam bukunya Ilmu Dakwah secara garis besar tiga cakupan metode dakwah, yaitu:

1. Bil Hikmah Berdakwah dengan memperhatikan situasi dan kondisi sasaran dakwah dengan menitikberatkan pada kemampuan-kemampuan mereka, sehingga di dalam menjalankan ajaran-ajaran Islam selanjutnya, mereka tidak lagi merasa terpaksa atau keberatan. Sebagai metode dakwah, hikmah diartikan bijaksana, akal budi yang mulia, dada yang lapang, hati yang bersih, dan menarik perhatian orang kepada agama dan Tuhan. Menurut Imam Abdullah bin Ahmad Mahmud An-Nasafi dalam buku Metode Dakwah karya M. Munir, mengartikan hikmah, yaitu: "Dakwah bilhikmah" adalah dakwah dengan menggunakan perkataan yang benar dan pasti, yaitu dalil yang menjelaskan kebenaran dan menghilangkan keraguan. Dari pengertian tersebut, M. Munir mengartikan hikmah merupakan kemampuan dan ketepatan daeci dalam memilih, memilah dan menyelaraskan teknik dakwah dengan kondisi objektif mad'u.

2. Mauizhaah Hasanah Terminologi mauizhaah hasanah dalam perspektif dakwah sangat populer. Istilah mauizhaah hasanah terdiri dari dua kata, mauizhaah dan hasanah. Kata mauizhaah berarti nasihat, bimbingan, pendidikan dan peringatan, sementara hasanah merupakan kebalikan dari sayyi eeah yang artinya kebaikan lawan kejelekan. Mauizhaah hasanah yaitu berdakwah dengan memberikan nasihatnasihat atau menyampaikan ajaran-ajaran Islam yang disampaikan itu dapat menyentuh hati mereka. Menurut Imam Abdullah bin Ahmad Mahmud An-Nasafi dalam buku Metode Dakwah karya M. Munir, mengartikan Mauizhaah Hasanah, yaitu: "alMauizhaah al-Hasanah" adalah (perkataan-perkataan) yang tidak tersembunyi bagi mereka, bahwa engkau memberikan nasehat dan menghendaki manfaat kepada mereka atau dengan al-Qur"an.

\section{Berdakwah Ditengah Pandemi}

Berdakwah di tengah situasi pandemic yang dapat dilakukan oleh setiap daeci pada masa pandemi Covid 19 adalah dakwah dengan menggunakan media yang berbasis Teknologi Informasi, seperti yang marak dilakukan saat pandemi covid 19 dengan menggunakan Media Zoom Meeting, Google Meet, Webex, atau aplikasi video konfren. Hal ini dilakukan sebagai sarana mengurangi penularan wabah virus secara massif. Berdakwah yang biasanya dilakukan dengan tatap muka, saat pandemi Covid 19 dilakukan menggunakan video konfren dari rumah masing-masing. Dengan demikian dakwah moderasi yang dilakukan masih bisa tetap berjalan, meskipun tidak secara langsung bertemu dengan mad'u. ini juga merupakan salah satu langkah yang mau tidak mau harus kita lakukakan karena dilihat dari situasi dan kondisi kita saat ini yang tidak memungkinkan untuk melakukakn tatap muka secara langsung, sehingga apapun kegiatan kita mau tidak mau hanya dilakukan hanya di rumah.

\section{KESIMPULAN}

Berdakwah di era sekarang ini tidak hanya dilakukan di dunia nyata saja tetapi di dunia virtual pun aktifitas berdakwah bisa kita lakukan baik itu menggunakan aplikai tambahan ataupun sekedar video call yang intinya pesan dan informasi ataupun ilmu yang ingin disampaikan tersampaikan 
dengan baik kepada mad'u. jadi pergunakan sebaik baiknya akses internet yang ada di era sekarang ini pergunakan dengan sebijak bijaknya dan jadilah orang yang paham dan melek akan teknologi. 


\section{Daftar pustaka}

https://id.wikipedia.org/wiki/Dakwah\#: :text=Dakwah\%20(Arab\%3A\%20\%D8\%AF\%D8\%B9

\%D9\%88\%D8\%A9\%E2\%80\%8E\%2C,berarti\%20panggilan \%2C\%20seruan $\% 20$ atau $\% 20$ ajakan.

M. Munir, Metode Dakwah, Cet. Ke-3, (Jakarta: Kencana, 2009) M. Munir, S.Ag, MA.

Metode Dakwah, (Jakarta:Kencana Prenada Media Group,2009) 